\title{
Zasada jawności finansów publicznych a jawność publicznego finansowania partii politycznych w Polsce
}

\section{Wprowadzenie}

Finanse publiczne stanowią istotne zagadnienie ustrojowe, czego formalnym przejawem jest ich ujęcie w strukturze Konstytucji RP w postaci odrębnego rozdziału. Wśród unormowań zawartych w ustawie zasadniczej nie ma jednak żadnego przepisu, który odnosiłby jawność do każdego przejawu tych zjawisk finansowych, a nie do niektórych ich aspektów. Z tego punktu widzenia zasada jawności finansów publicznych nie jest konstytucyjną regułą. Zasady ogólne są bowiem pojęciem ustrojowym, które w znaczeniu normatywnym jest ujmowane wąsko w kontekście wolności, praw, obowiązków człowieka i obywatela². Konstytucja RP nie rozpatruje tych reguł w aspekcie jawności finansowania środkami publicznymi. Niewątpliwie jednak występuje pomiędzy tymi czynnikami funkcjonalne powiązanie, gdyż jawność finansów publicznych jest także jednym ze środków realizacji wolności oraz praw człowieka i obywatela.

Konstytucja RP wyraźnie ustanawia jawność finansowania partii politycznych $^{3}$. Nakaz prowadzenia jawnej działalności finansowej wyodrębnia partie polityczne wśród innych form organizacji społeczeństwa obywatelskiego. Warto zauważyć, że Konstytucja RP nakłada na państwo obowiązek zapewnienia wolności tworzenia i działania nie tylko partii politycznych, lecz także związków zawodowych, organizacji społeczno-zawodowych rolników, stowarzyszeń, ruchów obywatelskich, innych dobrowolnych zrzeszeń oraz fundacji ${ }^{4}$. Jednak

* Dr hab. Andrzej Gorgol - Katedra Prawa Finansowego, Wydział Prawa i Administracji, Uniwersytet Marii Curie-Skłodowskiej w Lublinie.

${ }^{1}$ Zob. Rozdział X Konstytucji Rzeczypospolitej Polskiej z dnia 2 kwietnia 1997 r., Dz. U. $\mathrm{Nr} 78$, poz. 483 ze zm. (dalej: Konstytucja RP).

${ }^{2}$ Rozdział II Konstytucji RP zatytułowany Wolności, prawa, obowiazki człowieka i obywatela zawiera przepisy od art. 30 do art. 37 pogrupowane i nazwane jako Zasady ogólne.

${ }^{3}$ Zob. art. 11 ust. 2 Konstytucji RP.

${ }^{4}$ Zob. art. 12 Konstytucji RP. 
w odróżnieniu od ugrupowań politycznych te struktury organizacji społeczeństwa obywatelskiego nie są obowiązane do jawnego finansowania swojej działalności. Nakaz jawności finansów partyjnych może być postrzegany jako odstępstwo od ustrojowej wolności działania. Ogranicza on swobodę wyboru reguł gromadzenia i wydatkowania środków pieniężnych, która jest typowa dla podmiotów prawa prywatnego. Upodabnia zarazem pozycję prawną partii politycznych do jednostek sektora finansów publicznych, których finansowanie jest jawne ${ }^{5}$. Upublicznienie statusu ugrupowań politycznych jest następstwem objęcia ich także publicznym finansowaniem ze środków budżetu państwa ${ }^{6}$. Warto zauważyć, iż jedynie partie polityczne wraz z jednostkami samorządu terytorialnego są adresatem elitarnego subwencjonowania ${ }^{7}$. Stosowane jest ono niezależnie od ich dotowania, które jako egalitarna forma wydatkowania środków publicznych jest skierowane do znacznie szerszego kręgu beneficjentów, obejmującego także zwycięskie ugrupowania polityczne uczestniczące w wyborach $^{8}$.

Niewątpliwie jawność finansów partyjnych rozciąga się na wszelkie formy finansowania partii politycznej - zarówno prywatne, jak i publiczne. W zakresie wspierania przez państwo działalności ugrupowań politycznych środkami budżetowymi występuje sytuacja, gdy nakładają się zakresy obowiązywania konstytucyjnej zasady jawności finansowania partii politycznych i ustawowej reguły jawności finansów publicznych. Wydaje się zatem zasadne rozważenie wzajemnego oddziaływania obu tych zasad.

${ }_{5}^{5}$ Por. art. 9, art. 33 ust. 1 i art. 5 ustawy z dnia 27 sierpnia 2009 r. o finansach publicznych, Dz. U. Nr 157, poz. 1240 ze zm. (dalej: u.f.p.).

${ }^{6}$ Publiczne finansowanie ugrupowań politycznych powoduje zacieśnienie ich relacji z państwem i ,podkreślenie publicznego charakteru partii politycznych”. Zob. J. Sułkowski, Pozycja ustrojowoprawna partii politycznych w Polsce, Czechach i na Wegrzech, Łódź 2010, s. 282. Szerzej na temat patrz: A. Gorgol, Prawne aspekty publicznego finansowania partii politycznych $w$ Polsce i na poziomie europejskim, Lublin 2011, s. 202-203.

7 Zob. art. 112 ust. 1 pkt 3 i 6 u.f.p.

8 Zgodnie z art. 150 § i $§$, art. $151 \S 1$ i $§ 2$ ustawy z dnia 5 stycznia 2011 r. Kodeks wyborczy, Dz. U. Nr 21, poz. 112 ze zm., dotacja podmiotowa przysługuje partii politycznej, która powołała własny komitet wyborczy lub weszła w skład koalicyjnego komitetu wyborczego, który uczestniczył w wyborach do Sejmu, Senatu, Parlamentu Europejskiego. Kwota dofinansowania jest wprost proporcjonalna do liczby uzyskanych mandatów parlamentarnych. Z uwagi na sformułowaną w art. 25 ust. 1 ustawy z dnia 27 czerwca 1997 r. o partiach politycznych, t.j. Dz. U. z 2011 r. $\mathrm{Nr}$ 155, poz. 924 ze zm. (dalej: u.p.p.) regułę dopuszczającą finansowanie działalności partyjnej w zasadzie jedynie przez osoby fizyczne będące obywatelami polskimi i mające miejsce zamieszkania w Polsce, dotacje dla partii politycznych stosowane są wyjątkowo w okolicznościach opisanych w tej ustawie. Wyłącza to możliwość przekazywania ugrupowaniom politycznym innych dotacji wymienionych w ustawie o finansach publicznych, które nie mają charakteru dotacji podmiotowej w rozumieniu Kodeksu wyborczego. 


\section{Wykładnia prokonstytucyjna nakazów jawności}

Zasada jawności finansów publicznych, która ma źródło w przepisie ustawowym ${ }^{9}$, powinna być interpretowana w zgodzie z konstytucyjną regułą jawności publicznego finansowania partii politycznych ${ }^{10}$. Jedynie w ten sposób zostanie zrealizowane normatywne założenie prymatu Konstytucji RP wśród aktów prawnych $^{11}$, jej bezpośredniego stosowania ${ }^{12}$ oraz systemowej spójności aksjologicznej prawa ${ }^{13}$. Oznacza to, iż w sferze gromadzenia i wydatkowania środków pieniężnych przez ugrupowania polityczne występuje formalna hierarchia nakazów jawności, przejawiająca się w zróżnicowaniu ich mocy prawnej oraz przyznaniu standardowi konstytucyjnemu pozycji nadrzędnej wobec ustawowej zasady.

Wykładnia prokonstytucyjna zawęża zakres poszukiwania treści reguły jawności finansów publicznych, eliminując ustalenia nie tylko sprzeczne z jawnością finansowania partii politycznych, lecz także niespójne z ustrojowymi wartościami i instrumentami ich realizacji. Standardy konstytucyjne obowiązują w sferze zarówno przyzwoitej legislacji, jak i stosowania prawa. Z tego względu powinny być eliminowane również takie sposoby interpretowania reguły ustawowej jawności, które nie są wzajemnie sprzeczne z konstytucyjnym nakazem jawności, lecz wywołują kolizję w jego oddziaływaniu na realne stosunki społeczne.

Nie wydaje się zasadne postrzeganie konstytucyjnego standardu w ten sposób, że unifikuje on materię legislacyjną tak, iż treść jawności finansów publicznych zostaje niejako „wtłoczona” w zakres znaczeniowy jawności finansowania partii politycznych. Obie zasady nie są tożsame pod względem formalnym i merytorycznym ${ }^{14}$. Zróżnicowanie ich treści występuje w połączeniu $\mathrm{z}$ różnorodnością zakresu ich obowiązywania. Biorąc zatem pod uwagę kryterium relacji tych zasad, można wyróżnić trzy zakresy ich stosowania. Po pierwsze, przedział wspólny dla jawności finansów publicznych i jawności finansów partyjnych, który rozciąga się na publiczną formę finansowania działalności partyjnej środkami rozdysponowywanymi z budżetu państwa. Po drugie, przedział wyłącznego obowiązywania zasady jawności finansów publicznych, który w znacznej części

${ }^{9}$ Zob. art. 33 ust. 1 u.f.p.

${ }^{10}$ Zob. art. 11 ust. 2 Konstytucji RP.

${ }_{11}$ Zob. art. 8 ust. 1 Konstytucji RP.

${ }_{12}$ Zob. art. 8 ust. 2 Konstytucji RP.

${ }_{13}$ Szerzej na temat znaczenia art. 8 ust. 1 i 2 Konstytucji RP dla ustroju finansowego państwa patrz: T. Dębowska-Romanowska, Prawo finansowe. Część konstytucyjna wraz z częścia ogólna, Warszawa 2010, s. 105-109; eadem, Pojęcie i znaczenie konstytucjonalizacji ustroju i system finansowego państwa, [w:] P. J. Lewkowicz, J. Stankiewicz (red.), Konstytucyjne uwarunkowania tworzenia i stosowania prawa finansowego i podatkowego, Białystok 2010, s. 17-29.

${ }^{14}$ Brak jest podstaw normatywnych i merytorycznych do rozpatrywania zasad publicznego finansowania partii politycznych w opozycji do zasad budżetowych, chociaż mogą one mieć różne uzasadnienie aksjologiczne. Zob. A. Gorgol, op. cit., s. 220-221. 
wykracza poza sferę funkcjonowania ugrupowań politycznych. Po trzecie, zakres zastosowania tylko zasady jawności finansowania partii politycznych. Rozciąga się on na ich prywatną działalność finansową, a więc prowadzoną bez udziału środków publicznych.

Ustawa o finansach publicznych dopuszcza odstąpienie od przestrzegania zasady jawności gospodarowania środkami publicznymi, gdy z mocy umowy międzynarodowej lub odrębnych przepisów ich pochodzenie lub przeznaczenie zostało uznane za informację niejawną ${ }^{15}$. Utajnienie danych o środkach budżetowych wydatkowanych na rzecz partii politycznych narusza jednak konstytucyjny standard jawności ich finansowania. Oznacza to, iż Konstytucja RP nadaje zasadzie jawności finansów publicznych w zakresie odnoszącym się do działalności finansowej ugrupowań politycznych cechy specyficzne, odbiegające od jej ustawowego modelu, ale typowe dla ustrojowych wolności praw stosowanych bez żadnych wyjątków ${ }^{16}$. W ten sposób wzmocnieniu ulega znaczenie jawności w gospodarowaniu środkami publicznymi wydatkowanymi z budżetu państwa na wspieranie działalności partyjnej. Upodobnienie się pod względem oddziaływania ustawowego nakazu jawności do nielimitowanej, ustrojowej reguły jawności finansowania partii politycznych jest korzystne i służy zwiększeniu skuteczności jej wdrożenia. Prawne przyzwolenie na ograniczenie zakresu zastosowania jawności finansów publicznych mocą innych przepisów prawa mogłoby doprowadzić do sprzeczności pomiędzy tym rozwiązaniem a konstytucyjnym standardem jawności.

Warto zauważyć, że uregulowanie zasady jawności finansowania partii politycznych jest pełne w tym znaczeniu, iż ustalenie jej treści nie wymaga uwzględnienia innych, pozakonstytucyjnych przepisów prawa. Jak słusznie zauważono w literaturze przedmiotu ${ }^{17}$, pojęcia konstytucyjne nie powinny być interpretowane z wykorzystaniem definicji ustawowych, ani tym bardziej przepisów wykonawczych. Jawność finansów partyjnych ma treść ukształtowaną również konstytucyjnie, która nie może być modyfikowana mocą innych aktów prawnych. Z tego względu zawarta w ustawie o partiach politycznych regulacja tej jawności powinna uszczegóławiać rozwiązanie ustrojowe, a nie ograniczać jego treść lub zakres obowiązywania. Nie jest możliwe rozciągnięcie mocą tej ustawy zakresu jawności na jakieś dodatkowe informacje o partyjnych finansach, gdyż konstytucyjny standard nie przewiduje wyjątków od nakazu prowadzenia jawnej działalności partyjnej w pełnym jej zakresie.

${ }^{15}$ Zob. art. 33 u.f.p.

${ }^{16}$ Na przykład prawo do równego traktowania przez władze publiczne (art. 32 ust. 2 Konstytucji RP) i do opieki ze strony państwa w trakcie pobytu obywatela za granicą (art. 36 Konstytucji RP) nie jest ograniczane wyjątkami, a prawo do własności (art. 64 Konstytucji RP) oraz wolność działalności gospodarczej (art. 22 Konstytucji RP) mogą być limitowane.

${ }_{17}$ Zob. T. Dębowska-Romanowska, Pojęcie..., s. 17-18; eadem, Zdanie odrębne do wyroku Trybunału Konstytucyjnego z dnia 14.12.2004 r., sygn. K 25/03, OTK ZU 2004, nr 11A, poz. 116. 
Jawność finansów publicznych stanowi zagadnienie wykraczające poza ograniczone ramy materii ustawowej regulacji. Ustalenie treści i zakresu obowiązywania tej zasady wymaga uwzględnienia przepisów zawartych w różnych aktach prawnych, a nie tylko w ustawie o finansach publicznych. Warto zauważyć, iż ustawowa alternatywa podstaw prawnych utajnienia informacji o pochodzeniu lub przeznaczeniu środków publicznych jest myląca ${ }^{18}$. Ratyfikowane umowy międzynarodowe ogłoszone w Dzienniku Ustaw stanowią bowiem akty prawa powszechnie obowiązującego w Polsce, a ich przepisy mają odrębny charakter $\mathrm{w}$ stosunku do unormowań ustawy o finansach publicznych ${ }^{19}$. Postanowienia tych umów są zatem tożsame z ustawowym sformułowaniem ,odrębne przepisy”. Pomimo użytego spójnika „lub”, sugerującego według reguł wykładni językowo-gramatycznej występowanie logicznej alternatywy, należy uznać, że w rzeczywistości ona nie występuje. Sformułowanie ,na podstawie odrębnych przepisów lub jeżeli wynika to z umów międzynarodowych" powinno być interpretowane w ten sposób, iż odstępstwa od zasady jawności finansów publicznych wynikają z odrębnych przepisów, w tym z ratyfikowanych umów międzynarodowych. Legislacyjne odwołanie się do formy tych umów pełni funkcję przykładowej egzemplifikacji mocy prawnej odrębnego przepisu.

Niewątpliwie ustawa o partiach politycznych zawiera odrębne przepisy w stosunku do ustawy o finansach publicznych. Nie są one jednak istotne dla stosowania reguły jawności finansów publicznych. Prokonstytucyjna wykładnia tej zasady wyłącza bowiem utajnienie jakichkolwiek danych o finansowaniu działalności partyjnej. Eliminuje to konieczność ustalenia, czy z mocy ustawy o partiach politycznych lub innego przepisu wykonawczego wydanego na podstawie jej upoważnienia możliwe jest uznanie danych o gospodarce środkami publicznymi za informacje niejawne. Warto jednak zauważyć, iż ustawa o partiach politycznych nie może być stosowana w oderwaniu od ustawy o finansach publicznych. Partie polityczne nie są jednostkami sektora finansów publicznych, ale w zakresie gospodarowania środkami publicznymi uzyskanymi z budżetu państwa w formie subwencji lub dotacji podmiotowej są obowiązane do przestrzegania także ustawowego nakazu jawności finansów publicznych ${ }^{20}$.

\section{Treść nakazów jawności}

Przepisy ustanawiające jawność finansowania partii politycznych i jawność finansów publicznych mają identyczną strukturę redakcyjną. Przyjmują postać zdań oznajmujących, których treść stwierdza występowanie cechy jawności.

\footnotetext{
18 Zob. art. 33 ust. 2 u.f.p.

19 Zob. art. 91 ust. 1 i 2 Konstytucji RP.

${ }^{20}$ Wynika to wprost $\mathrm{z}$ art. 4 ust. 1 pkt 2 stosowanego w zw. $\mathrm{z}$ art. 33 ust. 1 u.f.p.
} 
W ustawie o finansach publicznych punktem odniesienia jest gospodarka środkami budżetowymi, a w Konstytucji RP - finansowanie partii politycznych ${ }^{21}$. W obu regulacjach jawność jest ujmowana w sposób przedmiotowy z pominięciem podmiotów, do których jest skierowana norma prawna. W ustawie zasadniczej pojawia się, co prawda, kategoria podmiotowa partii politycznych, ale jest ona użyta w kontekście ich finansowania, a więc ma charakter dopełnienia definiowanej przedmiotowo cechy.

Niewątpliwie ustalenie w ramach wykładni językowo-gramatycznej, że konstytucyjny i ustawowy standard jawności nie mają wyraźnej formy nakazów określonego zachowania, nie wyklucza, iż nie mają one takiej treści. Rozstrzygnięcie tej kwestii wymaga sięgnięcia do innych metod interpretacji przepisów prawa, a w szczególności wykładni systemowej i celowościowej.

W Konstytucji RP przepis ustanawiający jawność finansowania partii politycznych ma formę redakcyjną ust. $2 \mathrm{w}$ jej art. 11 . W ramach wykładni systemowej ${ }^{22}$ konstatacja ta wywołuje istotne następstwa interpretacyjne. Korzystając w drodze analogii z powszechnie akceptowanych szczegółowych zasad przyzwoitej legislacji - które ujęte są w normatywnej formule rozporządzania w sprawie zasad techniki prawodawczej ${ }^{23}$ - można stwierdzić, że ustrojowy standard jawności dopełnia funkcjonalnie treść zawartą w ustępie pierwszym art. 11 Konstytucji RP. Powinien być zatem odczytywany w kontekście wolności tworzenia i działania partii politycznych oraz zasad i celów zrzeszania się obywateli w ugrupowania polityczne. Nie stanowi on samodzielnej regulacji, chociażby z tego powodu, iż odrębny artykuł ujmuje każdą samodzielną myśl ${ }^{24}$. Zgodnie z zasadami techniki prawodawczej podział przepisu na ustępy jest możliwy tylko w alternatywnych sytuacjach $^{25}$. Po pierwsze, gdy samodzielną myśl wyraża zespół zdań. Po drugie, gdy między zdaniami wyrażającymi samodzielne myśli występują powiązania treściowe, ale treść żadnego $\mathrm{z}$ nich nie jest na tyle istotna, by została wydzielona w odrębnym artykule. Jak już wspomniano, jawność finansowania partii politycznych pozostaje w związku merytorycznym z zasadami działalności partyjnej. Stanowi ona jednak kluczowe zagadnienie dla prawidłowego funkcjonowania nie tylko tych ugrupowań, ale również demokratycznego państwa prawa, społeczeństwa obywatelskiego, a nawet ma wpływ na przestrzeganie praw człowieka i obywatela. Wynika z tego, że struktura redakcyjna art. 11 Konstytucji RP

${ }^{21}$ Por. art. 33 ust. 1 u.f.p. i art. 11 ust. 2 Konstytucji RP.

22 Jedną z dyrektyw tej wykładni jest argumentum a rubrica. Nakazuje interpretowanie przepisu z uwzględnieniem jego miejsca w systematyce aktu prawnego. Zob. np. J. Wróblewski, Rozumienie prawa i jego wykładnia, Wrocław 1990, s. 74; L. Morawski, Wykładnia w orzecznictwie sądów. Komentarz, Toruń 2002, s. 198-199.

${ }^{23}$ Rozporządzenie Prezesa Rady Ministrów z dnia 20 czerwca 2002 r. w sprawie „Zasad techniki prawodawczej”, Dz. U. Nr 100, poz. 908 (dalej: z.t.p.).

${ }^{24}$ Zob. $\S 55$ ust. 1 z.t.p.

${ }^{25}$ Zob. $\S 55$ ust. 3 i 4 z.t.p. 
odzwierciedla zespół zdań, które odnoszą się do wspólnego, wieloaspektowego zagadnienia $^{26}$.

Wydaje się, iż w ramach wykładni celowościowej unormowania nakazu jawności finansowania partii politycznych można wyróżnić zarówno jego treść negatywną, jak i pozytywną. Negatywny aspekt jest widoczny w ograniczeniu zakresu obowiązywania konstytucyjnej wolności. Z kolei pozytywna strona unormowania wiąże się z takim obowiązkiem zachowania, które powinno doprowadzić do kształtowania finansów partii politycznych i otoczenia ich działalności, aby jawność sprzyjała wolnej rywalizacji ugrupowań politycznych oraz prawidłowemu wykonywaniu ich funkcji.

Poddanie finansowania działalności partyjnej władczemu oddziaływaniu państwa za pomocą instrumentów regulacyjnych i reglamentacyjnych oznacza odstępstwo od założenia wolności tworzenia i działania partii politycznych oraz ograniczenia aktywności organów demokratycznego państwa prawa do jej przestrzegania. Konstytucyjne sformułowanie: „Rzeczpospolita Polska zapewnia wolność" wiąże się z nałożeniem na organy państwowe nakazu zachowania się w sposób prowadzacy do zrealizowania tego standardu. Skoro słowo „zapewnić" nie zostało zdefiniowane dla celów normatywny $\mathrm{ch}^{27}$, powinno być ono interpretowane według reguł typowych dla języka polskiego ${ }^{28}$. Słownikowym desygnatem ${ }^{29}$ tego pojęcia są przede wszystkim określenia: „czynić coś pewnym; sprawiać, że stanie się coś korzystnego dla kogoś lub dla siebie; gwarantować komuś lub sobie coś". Warto także zwrócić uwagę na drugie znaczenie analizowanego słowa, które jest zawarte w sformułowaniach: „starać się przekonać kogoś o czymś; usunąć czyjeś wątpliwości; oświadczyć komuś, iż coś jest lub będzie na pewno; zaręczyć; upewnić o czymś". Ta wieloznaczność przekłada się na odmienne, ale równoprawne sposoby podejścia do ustalenia treści konstytucyjnego standardu. $\mathrm{W}$ podstawowym ujęciu jawi się on jako dyrektywa postępowania, a więc aktywnego zachowania się jego adresata. Natomiast w drugim znaczeniu stanowi zapewnienie, czyli wypowiedź mającą na celu przekonanie kogoś o czymś; oświadczenie o czymś, co jest lub będzie na pewno. Niewątpliwie redakcja omawianego

${ }^{26} \mathrm{~W}$ wielu orzeczeniach sądy przyjmują takie, a nie inne znaczenie danego przepisu, wnioskując, że skoro artykuł stanowi pewną samodzielną całość, to nie należy przyjmować takiej interpretacji, która zakładałaby, że jakiś fragment danego artykułu nie jest związany z pozostałą częścią tego przepisu. Natomiast jeśli jakieś zdanie jest jedynie ustępem, a nie osobnym artykułem, oznacza to, że nie stanowi ono w pełni samodzielnej myśli, lecz jest fragmentem większej całości i nie może być interpretowane w oderwaniu od tej całości.

${ }^{27}$ Warto zauważyć, iż zostały sformułowane reguły prawidłowej legislacji, które ograniczają możliwość tworzenia definicji normatywnych do sytuacji wymienionych w $§ 146$ u.z.p. Skoro sformułowanie ,zapewnia” występuje w różnych przepisach konstytucyjnych oraz jest wieloznaczne, przyczynę jego niezdefiniowania można racjonalnie uzasadnić jedynie tym, iż jest ono powszechnie zrozumiałe.

${ }^{28}$ Zgodnie z $\S 8$ ust. 1 z.t.p. w aktach prawnych należy się posługiwać poprawnymi wyrażeniami językowymi (określeniami) w ich podstawowym i powszechnie przyjętym znaczeniu.

${ }^{29}$ M. Szymczak (red.), Słownik języka polskiego PWN, t. 3: R-Z, Warszawa 1999, s. 880; M. Bańko (red.), Stownik języka polskiego, t. 6: Wde-Żyz, Warszawa 2007, s. 338-339. 
przepisu konstytucyjnego nawiązuje do formy zapewnienia, czyli oświadczenia o pewności występowania cechy jawności finansowania partii politycznych, a nie do oświadczenia, iż organy demokratycznego państwa podejmą działania, aby wystąpił taki stan faktyczny. Nie wyklucza to jednak odczytywania tego zapewnienia jako także oświadczenia o zobowiązaniu się przez państwo do eliminowania patologii naruszających standard jawności finansów partyjnych. Należy zatem uznać, że regulacja konstytucyjna zawiera zarówno nakaz postępowania, oświadczenie wiedzy diagnozujące stan finansów partyjnych, jak i oświadczenie woli o działaniu w celu zapewnienia jej skutecznego przestrzegania. Logiczną konsekwencją stwierdzenia, że jawność już charakteryzuje finanse partyjne, jest brak uzasadnienia do podejmowania działań wdrażających ten standard. W takim przypadku rola państwa powinna być ograniczona do korygowania obecnego systemu w sposób eliminujący rozwiązania prawne niezgodne z unormowaniem konstytucyjnym oraz patologie związane z unikaniem przestrzegania reguł jawności.

Traktowanie nakazu jawności finansowania partii politycznych jako instrumentu zapewnienia wolności ich działania uzasadnia stwierdzenie o spójności aksjologicznej obu części redakcyjnych art. 11 Konstytucji RP. Pluralizm polityczny w warunkach demokracji parlamentarnej, społeczeństwo obywatelskie, ochrona praw człowieka i obywatela stanowią wartości ustrojowe, które uzasadniają poddanie ugrupowań politycznych powszechnemu pod względem obowiązywania, publicznemu w swej treści i bezwzględnie obowiązującemu rygorowi ujawnienia informacji o finansach partyjnych. W zakresie publicznego finansowania partii politycznych taką wartością są także finanse publiczne, a szczególności dbałość o ograniczenie deficytu całego systemu finansów publicznych, państwowego długu publicznego, właściwe zarządzanie środkami publicznymi. Niewątpliwie rolą Konstytucji RP nie jest regulowanie szczegółowych katalogów prawnie dopuszczalnych instrumentów ochrony tych wartości, gdyż takie zagadnienia wykraczają poza zakres ustrojowych zasad. Stanowią one materię regulacji ustawowej oraz przepisów wydawanych na podstawie, w granicach i w wykonaniu upoważnień ustawowych. Niemniej jednak warto zauważyć, iż konstruowanie wykazu środków stosowanych w celu zapewnienia jawności finansów publicznych podlega konstytucyjnym ograniczeniom. Zarówno materialne, jak i proceduralne standardy ustrojowe istotnie zawężają swobodę legislacyjną. Jedynie tytułem przykładu można wskazać na konieczność poszanowania w równym stopniu wolności i równości partii politycznych ${ }^{30}$, adekwatności nakładanego obowiązku dla zapewnienia celu legislacyjnego i przestrzegania reguł przyzwoitej legislacji ${ }^{31}$.

30 W Polsce wolność i równość partii politycznych wynika z konstytucyjnie chronionej zasady pluralizmu politycznego. Por. art. 11 i art. 32 Konstytucji RP. Szerzej na ten temat patrz: M. Granat, Zasada pluralizmu politycznego, [w:] W. Skrzydło (red.), Polskie prawo konstytucyjne, Lublin 1998, s. 147; W. Gulczyński, Demokratyczna reguła pluralizmu politycznego, [w:] W. Sokolewicz (red.), Zasady podstawowe polskiej konstytucji, Warszawa 1998, s. 174.

31 Mają one źródło przede wszystkim w art. 2 Konstytucji RP. 
Ustawa o finansach publicznych wyraźnie odnosi jawność finansów publicznych do gospodarowania środkami publicznymi ${ }^{32}$. Natomiast w tytule jej Rozdziału 4 zawartego w Dziale I jawność jest cechą finansów publicznych. Pojawia się zatem wątpliwość, jaki jest zakres znaczeniowy nakazu jawności, skoro finanse publiczne nie są tożsame z gospodarką środkami publicznymi. Według definicji legalnej finanse publiczne to wszelkie procesy związane z gromadzeniem i rozdysponowaniem środków publicznych, a zatem nie tylko te zjawiska finansowe, które wymienione są enumeratywnie w ustawowym katalogu ${ }^{33}$. Wyliczenie to pełni funkcję przykładowej egzemplifikacji tych procesów, które są najbardziej typowe dla finansów publicznych. W ustawowym katalogu nie została wymieniona gospodarka środkami publicznymi, chociaż uwzględniono jej niektóre przejawy. Niewątpliwie wszystkie przykłady egzemplifikacji procesów charakterystycznych dla finansów publicznych mogą być zarazem uznane za czynności z zakresu gospodarki środkami publicznymi. Jednak nie można utożsamić obu tych pojęć. Gospodarowanie środkami publicznymi obejmuje także działania, które nie polegają bezpośrednio na gromadzeniu lub wydatkowaniu środków publicznych, ale tworzą przesłanki materialne i formalne do prowadzenia działalności finansowej. Dotyczy to np. sfery stanowienia przepisów finansowych, sporządzania planów finansowych, kontrolowania ich wykonania, tworzenia struktur organizacyjnych sektora finansów publicznych. Gospodarka środkami publicznymi jest istotnym zagadnieniem dla systemu finansów publicznych. Potwierdzeniem normatywnym tej tezy jest chociażby jej uwzględnienie w tytule Rozdziału 5 Działu I ustawy o finansach publicznych. Niewątpliwie brak definicji legalnej pojęcia ,gospodarka środkami publicznymi”, występującego zarówno w języku prawnym, jak i prawniczym, powoduje wątpliwości interpretacyjne także przy ustalaniu treści nakazu prowadzenia tej gospodarki w sposób jawny.

W literaturze przedmiotu ${ }^{34}$ jawność finansów publicznych jest uznawana za regułę systemową ${ }^{35}$, a więc mającą zastosowanie w całym systemie finansów publicznych. Cecha jawności nie powinna być zawężana do budżetu, ale postrzegana jako zasada budżetowa ${ }^{36}$, gdyż ma zastosowanie również do gospodarki

32 Zob. art. 33 ust. 1 u.f.p.

33 Zob. art. 3 u.f.p.

34 Patrz np.: C. Kosikowski, Polskie prawo finansowe na tle prawa Unii Europejskiej, Warszawa 2008, s. 316; A. Komar, Finanse publiczne w gospodarce rynkowej, Bydgoszcz 1996, s. 87-90.

35 Zasada systemowa opisuje normatywne lub postulowane przez doktrynę cechy całego systemu finansów publicznych, a nie poszczególnych jego elementów składowych. Niekiedy jest ona określana jako zasada ogólna prawa finansowego. Zob. np. C. Kosikowski, Prawo finansowe. Część ogólna, Warszawa 2003, s. 42-43. Taka nomenklatura nie jest jednak trafna, gdyż czym innym są zasady prawa, a czym innym zasady systemu finansów publicznych. Reguły systemowe mogą być także typowymi postulatami doktryny, które nie mają normatywnego charakteru.

${ }^{36}$ Etiologia jawności jest związana z genezą budżetu i z historią parlamentaryzmu. Szerzej na temat ewolucji postrzegania jawności w gospodarowaniu środkami publicznymi patrz: B. Kucia-Guściora, Komentarz do art. 33, [w:] P. Smoleń (red.), Ustawa o finansach publicznych. Komentarz, Warszawa 2012, s. 315-316. 
pozabudżetowej środkami publicznymi. Wykładnia językowo-gramatyczna ustawowego nakazu jawności prowadzi do wstępnego wniosku, iż jest on treścią zasady gospodarowania środkami publicznymi. Paradoksalnie jednak te zdawałoby się bezsporne ustalenia interpretacyjne nie wytrzymują konfrontacji z wnioskami mającymi źródło w wykładni wewnątrzsystemowej. Przyjmując bowiem założenie racjonalności działań legislacyjnych, należy ograniczyć katalog zasad gospodarowania środkami publicznymi w znaczeniu normatywnym wyłącznie do zasad uregulowanych w Rozdziale 5 Dziale I ustawy o finansach publicznych. Jawność gospodarki środkami publicznymi stanowi regułę systemową, której istotne znaczenie uzasadnia jej pominięcie w grupie zasad technicznych odnoszących się do gospodarowania tymi środkami ${ }^{37}$.

Podobnie jak finansowanie partii politycznych spełnia standard jawności, tak jawność finansów publicznych może być postrzegana jako normatywna cecha aktualnego systemu finansów publicznych. Z ustawy o finansach publicznych wynika bowiem zapewnienie, iż gospodarka środkami publicznymi i finanse publiczne są jawne. Niewątpliwie z obiema regułami łączy się nakaz takiego postępowania, które ma na celu ujawnienie danych finansowych. W ramach analogii można także uznać, iż państwo złożyło oświadczenie woli - zapewnienie, iż nie będzie tolerowało sytuacji, gdy ustawowy standard jawności nie będzie realizowany.

Inaczej niż w przypadku konstytucyjnego rozwiązania, ustawa o finansach publicznych określa kazuistycznie katalog środków służących realizacji zasady jawności finansów publicznych ${ }^{38}$. Regulacja ta nie zawiera bezpośrednich odniesień do publicznego finansowania partii politycznych. Oczywiście nie oznacza to, że jest ona neutralna z punktu widzenia działania ugrupowań politycznych i realizowania konstytucyjnego standardu ich jawności. Katalog ustawowy zawiera bowiem instrumenty bardziej uniwersalne, które są stosowane w szerszym zakresie podmiotowym i przedmiotowym, obejmującym nie tylko partie polityczne i ich działalność finansową.

Warto podkreślić, iż wyspecjalizowanym instrumentem rozdysponowania środków z budżetu państwa jest subwencja na rzecz partii politycznych. Ustawa o finansach publicznych nie wymienia wśród instrumentów realizacji nakazu jawności finansów publicznych podawania do publicznej wiadomości danych o kwotach takich wydatków budżetowych. Niewątpliwie takie informacje są jawne ze względu na obowiązywanie konstytucyjnego standardu jawności finansowania partii politycznych, który jest realizowany przez obowiązek sporządzania i upublicznienia sprawozdań finansowych wymaganych przez ustawę o partiach politycznych $^{39}$. Zarówno informacja finansowa o otrzymanej subwencji oraz o po-

${ }^{37}$ Zasady gospodarowania środkami publicznymi powtarzają, uzupełniają lub precyzują zasady ogólne. Zob. E. Ruśkowski, Komentarz do art. 42, [w:] E. Ruśkowski, J. M. Salachna (red.), Nowa ustawa o finansach publicznych wraz z ustawa wprowadzająca. Komentarz praktyczny, Gdańsk 2010, s. 170-171.

${ }^{38}$ Zob. art. 34 u.f.p.

${ }^{39}$ Por. art. 34 ust. 1 i art. 38 ust. 1 u.p.p. 
niesionych z subwencji wydatkach, jak i sprawozdanie o źródłach pozyskania środków finansowych, w tym o kredytach bankowych i warunkach ich uzyskania oraz o wydatkach poniesionych ze środków Funduszu Wyborczego w poprzednim roku kalendarzowym, zawierają zindywidualizowane dane finansowe o beneficjentach środków publicznych wydatkowanych z budżetu państwa. Charakteryzują się one także konkretnością informacji o kwotach nie tylko uzyskanego przez partię polityczną zasilenia finansowego, ale także ponoszonych przez nią wydatkach.

Z kolei ustawa o finansach publicznych wprowadza obowiązek upublicznia danych finansowych zarówno zbiorczych, jak i skonkretyzowanych. W odniesieniu do dotacji budżetowych, a więc także dotacji dla partii politycznych, ma on węższy zakres obowiązywania. Nie występuje bowiem obowiązek ujawnienia danych o sposobie wykorzystania przez ich beneficjenta otrzymanych środków publicznych. Należy zatem uznać, iż publikacja dokumentów finansowych sporządzanych na podstawie ustawy o partiach politycznych w większym stopniu realizuje standard jawności niż instrumenty przewidziane w ustawie o finansach publicznych. W tym kontekście pominięcie w katalogu środków zapewniających jawność finansów publicznych upubliczniania kwot subwencji dla partii politycznych nie stanowi błędu legislacyjnego i nie ma praktycznych konsekwencji dla zagwarantowania przestrzegania jawności finansów publicznych. Konstytucyjny standard jawności finansowania partii politycznych wymusza bowiem ujawnienie danych finansowych o większym stopniu szczegółowości i rozleglejszym zakresie tematycznym niż nakaz jawności gospodarki budżetowej. Skoro rozwiązanie ustrojowe niejako konsumuje obowiązek z ustawy o finansach publicznych, zbędne jest zdublowanie obowiązku ujawniania tych samych danych zarówno przez wykonawcę budżetu państwa, jak i beneficjenta środków publicznych.

Konstytucja RP przyznaje każdemu obywatelowi prawo do uzyskania informacji publicznych, którego zakres przedmiotowy rozciąga się na dane o działalności organów władzy publicznej i osób pełniących funkcje publiczne, organów samorządu gospodarczego i zawodowego, a także innych podmiotów w zakresie wykonywanych przez nich zadań publicznych i gospodarowania mieniem publicznym ${ }^{40}$. Niewątpliwie uprawnienie to może być realizowane także w sferze finansów publicznych ${ }^{41}$. Z kolei partie polityczne nie są prawnie obowiązane do wykonywania żadnych funkcji publicznych, chociaż odgrywają istotną rolę w sferze publicznej. Nie gospodarują także mieniem skarbowym lub samorządowym. Z tego powodu nie odnosi się do nich konstytucyjne prawo obywatelskiego dostępu do informacji publicznych. Treść zasad jawności finansowania

${ }^{40}$ Zob. art. 61 ust. 1 Konstytucji RP.

${ }^{41}$ Jawność publicznej gospodarki finansowej stanowi jedną z gwarancji realizacji konstytucyjnej zasady prawa do informacji o działalności organów władzy publicznej, a także osób pełniących funkcje publiczne. Zob. W. Miemiec, Komentarz do art. 33, [w:] M. Karlikowska, W. Miemiec, Z. Ofiarski, K. Sawicka (red.), Ustawa o finansach publicznych. Komentarz, Wrocław 2010, s. 90. 
partii politycznych i jawności finansów publicznych nie zawiera uprawnienia podmiotu do uzyskania takich informacji. Zarówno powołanie się na ustawowe, jak i konstytucyjne unormowania prawa obywatelskiego do uzyskania informacji publicznej nie jest wystarczające do uznania, iż na partii politycznej spoczywa obowiązek przekazania obywatelowi żądanych przez niego informacji finansowych. Wniosek ten uzasadnia także pominięcie ugrupowań politycznych wśród adresatów ustawowego obowiązku udostępnienia informacji publicznych ${ }^{42}$. Skoro jednak Konstytucja RP nie ogranicza podmiotowo beneficjentów jawności finansowania działalności partyjnej, należy uznać, iż bez względu na ich status wszelkie podmioty są uprawnione do uzyskania dostępu do danych finansowych partiii ${ }^{43}$.

\section{Podsumowanie}

We wspólnym zakresie obowiązywania konstytucyjnego i ustawowego nakazu jawności występuje ich wzajemne oddziaływanie, wywołujące efekt synergii. Dotyczy to wzmocnienia stopnia jawności zarówno finansowania partii politycznych, jak i finansów publicznych.

$\mathrm{Z}$ uwagi na fundamentalną rolę Konstytucji RP w polskim systemie prawa wpływ jej oddziaływania na treść i stosowanie ustawy o finansach publicznych jest oczywisty. Można zarazem stwierdzić znaczny stopień siły tego oddziaływania. W zakresie wspólnego obowiązywania jawności finansów publicznych i finansowania partii politycznych standard jawności gospodarowania środkami publicznymi nabywa nowe, specyficzne cechy odbiegające od typowego rozwiązania ustawowego. Prokonstytucyjna wykładnia ustawy o finansach publicznych eliminuje możliwość utajnienia na podstawie odrębnych przepisów jakichkolwiek informacji o środkach budżetu państwa przeznaczonych na wsparcie ugrupowań politycznych. Prowadzi to także do upodobnienia się zasady jawności finansów publicznych do tych zasad ustrojowych, które mają bezwzględny charakter, gdyż nie występuje możliwość odstąpienia od obowiązku ich przestrzegania. Pozytywny wpływ jawności finansowania partii politycznych jest także zauważalny przy ustalaniu niejednoznacznej treści ustawowej reguły jawności.

Oddziaływanie standardu jawności finansów publicznych na nakaz jawności finansowania partii politycznych występuje w ograniczonym zakresie i funkcjonalnym powiązaniu, ale ma ono intensywne natężenie. Pojęcia konstytucyjne nie mogą być interpretowane z wykorzystaniem ustawowych definicji. Luki konstrukcyjne ustawy zasadniczej nie mogą być eliminowane przez stosowanie wprost rozwiązań innych aktów prawnych, a jej regulacje nie powinny być „wtłaczane”

${ }^{42}$ Zob. art. 4 ustawy z dnia 6 września 2001 r. o dostępie do informacji publicznej, Dz. U. Nr 112, poz. 1198 ze zm.

${ }^{43}$ A. Gorgol, op. cit., s. 227. 
w zakres materii ustawowych unormowań. $\mathrm{Z}$ tego względu jawność finansów publicznych nie jest pomocną dyrektywą interpretacyjną dla odkodowania norm ustrojowych, ale stanowi wskazówkę prakseologiczną w doborze działań zmierzających do skutecznego zrealizowania celów konstytucyjnych. Publiczne finansowanie partii politycznych jest formą finansów partyjnych, która najpełniej realizuje zasadę jawności ich finansowania. Wynika to przede wszystkim z obowiązującego w sektorze finansów publicznych nakazu prowadzenia jawnej gospodarki środkami publicznymi. $Z$ tego względu rozszerzenie zakresu wykorzystania środków publicznych w finansowaniu działalności partyjnej stanowi środek realizacji konstytucyjnego standardu jawności.

Studium niniejszego przypadku pozwala na sformułowanie ogólniejszej konkluzji, iż ustawowe zasady finansów publicznych, gospodarki środkami publicznymi i reguły budżetowe są poddane silnemu oddziaływaniu regulacji konstytucyjnej. Ustalenie ich istoty, treści i zakresu obowiązywania wymaga stosowania prokonstytucyjnej wykładni przepisów zawartych w ustawie o finansach publicznych i innych aktach prawnych, gdyż pominięcie w procesie wykładni fundamentalnej roli ustawy zasadniczej może spowodować istotne błędy interpretacyjne. 